\title{
Characterisation and Flotation of a Weathered Platinum Group Metal Ore
}

\author{
Mohale Letseli ${ }^{1}$, Willie Nheta ${ }^{1}$, Arno Steinmuller ${ }^{2}$ \\ ${ }^{1}$ University of Johannesburg \\ P.O.BOX 17011, Doornfontein 2028, Johannesburg, South Africa \\ mohale.letseli@ccmsa.co.za; wnheta@uj.ac.za \\ ${ }^{2}$ Lonehill Office Park, Lonehill Sandton \\ Johannesburg, South Africa \\ arno@eprontech.com
}

\begin{abstract}
In this paper, the effect of weathering on the mineralogy and flotation performance of a weathered Platinum group metal (PGM) ore was investigated. A comprehensive characterisation of the weathered ore was carried out, where physical, chemical, and mineralogical and liberation properties of the sample were determined. The performance of the weathered ore during flotation was investigated using a pilot plant. It was found that the ore contains 3g/t of 4E PGMs ( $\mathrm{Pt}, \mathrm{Pd}, \mathrm{Ru}$ and $\mathrm{Au}$ ). An average recovery of the $4 \mathrm{E}$ PGMs was between 25 to $92 \%$ depending on the depth of the pit. The average selectivity was trending upwards as mining progresses to deeper depth, but there is insufficient data at this point in time to determine whether there is a good correlation. More work will be done on determining the degree of weathering with depth.
\end{abstract}

Keywords: Platinum Group Metals, Flotation, Selectivity Index, Upper Group, Weathered Ores.

\section{Introduction}

The Bushveld Igneous Complex (BIC) of South Africa has the world's largest reserves of platinum group metals (PGMs) found in the Merensky, Upper Group 2 (UG2) and Platreefs [1]. Due to depletion of high grade ore in the Merensky reef and high operating cost, most platinum mine operations in South Africa have drifting towards mining and processing UG2 ore. Most mines process the UG2 ore from open pits and routinely suffers from low and erratic platinum group element (PGE) flotation recoveries. This is due to changes in mineralogy of the ore as a results of oxidation. In the past, these ores were left in situ, stockpiled or discarded owing to their poor flotation recoveries.

In the western Bushveld complex, PGMs are found in six different seams namely the MG1, MG2, MG3, MG4, LG6 andLG6A. Of the six seems, MG4 contains the highest grade of PGMs of approximately 4 grams per ton and Chromite content of $60-90 \%$ [2] Al these seams are categorised as UG2 ore. These seams are generally processed for chromite recovery, but they can however be used as a source of the PGMs. These seams lie close the surface and most of the ore is oxidised. Open pit mining method are used to mine them. Attempts have been made to try and recover the PGMs using the conventional flotation circuits. However, low PGM recoveries and high chromite recoveries have been witnessed. Parameters such as degree of weathering, grain sizes, amount of naturally floating gangue (NFG), types of regents and liberation plays vital roles in the flotation efficiencies of these ores [3]. The degree of weathering is determined by the depth of the seam from the surface.

There is need to try and correlate the degree of weathering to pit depth. This will determine the efficiency of the flotation circuit and reduces cost. It is necessary to obtain optimum flotation conditions that will give better recoveries and design a suitable flotation circuit. Choice of reagents used depends on the mineralogy of the ore. Apart from high PGM recoveries, it is necessary to monitor the amount of chromite that ends up in the final concentrate. Most smelters are designed to accept a certain amount of chromite (around 3 modal \%) in the PGM concentrate [5,6]. Where the amount of chromite exceeds 3\%, the PGE grade in the flotation concentrate is reduced with significant consequences for the downstream processes [7,8].

In this study, a comprehensive characterisation of the weathered UG2 ore is presented and the effects of weathering on PGMs flotation efficiencies from MG4 are investigated. 


\section{Methodology Materials and Methods}

The ore sample used was sourced from one of the PGMs mining company in Limpopo province, South Africa. The ore was obtained from an open pit mine. The reagents used in the flotation of the ore were obtained from SENMIN South Africa. These are sodium isobutyl xanthate (SIBX), Sendep 30D and Senfroth 200 as a collector, depressant and frother respectively. 2.1. Characterisation

The chemical composition of the sample was determined using a Rigaku ZSX Primus II X-Ray fluorescence (XRF) and Nickel sulphide fire assaying. The mineralogical phases were obtained using Rigaku Ultima IV X-ray diffractometer (XRD) and the surface topography using SEM and EDs. Particle size distribution of the slurry fed into the flotation circuit was determined using sieves.

\subsection{Methods}

Flotation experiments.

A pilot flotation plant consisting of a low intensity magnetic separator (LIMS), a wet high intensity magnetic separator (WHIMS), a rougher, scavenger and cleaner flotation cell was used for the flotation experiments. The flotation circuit is shown in Figure 1. The tailings obtained from a chromite recovery circuit were conditioned in a condition tank using $40 \mathrm{~g} / \mathrm{t}$ of the frother and $200 \mathrm{~g} / \mathrm{t}$ each of the collector and depressant. The slurry contained $30 \%$ solids at a grind of P80 passing $75 \mu \mathrm{m}$. The ore was floated in the rougher cell producing a concentrate that was sent straight to the cleaner cell. The rougher tailings were treated first with LIMS followed by WHIMS and then conditioned again using $200 \mathrm{~g} / \mathrm{t}$ each of collector and depressant. It was then floated in the scavenger cell at $30 \%$ solids. The scavenger concentrate was also treated by the cleaner cell. The Scavenger and the cleaner tailings were the final tailings. Samples were collected using 5L buckets at points shown in Figure 1. The samples were filtered, dried and sent to Mintek laboratory, South Africa for analysis. They were analysed for 4E PGE (Pt, Pd, Ru and $\mathrm{Au}$ ) and chromite content. The 4E PGE recovery and mass pull were then calculated using equation 1 and 2 respectively

$$
\% \text { Recovery }=\left(\frac{C c *(f-t)}{f *(C c-t)}\right) * 100
$$

\footnotetext{
Where

Cc: Concentrate grade

$f:$ Feed grade

$t$ : Tailings grade
}

Mass Pull $(\%)=$ Dry mass of cleaner conc/Total dry massof feed*100 


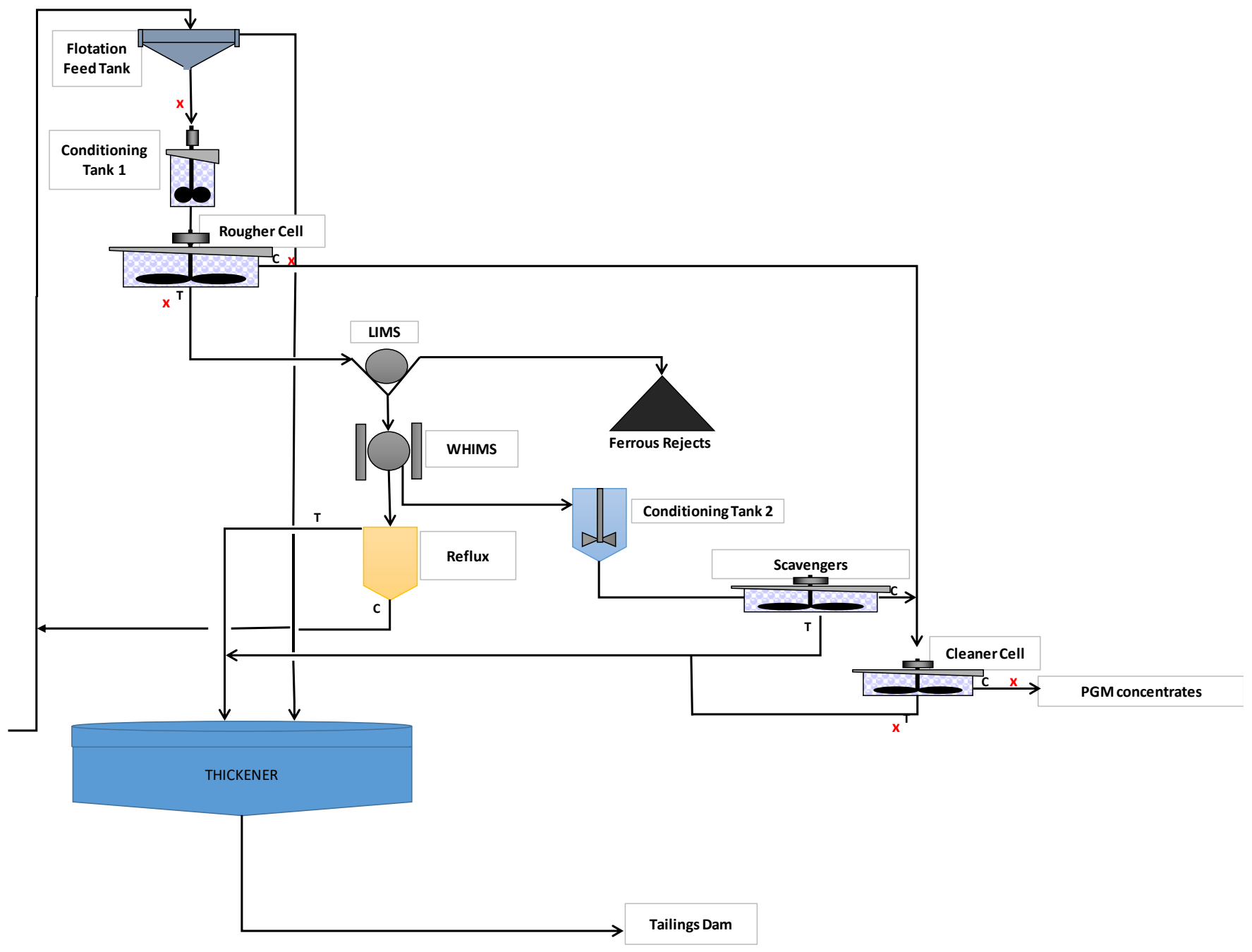

Fig. 1: Flotation Pilot Plant.

\section{Results and discussion}

\subsection{Characterisation}

The chemical composition of the feed was obtained using XRF and the results are shown in Table 1. Since the Platinumgroup minerals are extremely low in concentrations, they were not detected by this equipment. It is clear from Table 1 that the slurry still contains a high \% of chromite (26.24\%) and $\mathrm{Fe}(31.85 \%)$. Apart from that, it contains low base metal content. There is need to establish the degree of weathering of these base metal sulphides since they are associated with PGMs.

Table 1: Chemical Composition of the slurry feed to the flotation circuit.

\begin{tabular}{|l|c|c|c|c|c|c|c|c|c|c|}
\hline Element & $\mathrm{Na}$ & $\mathrm{Mg}$ & $\mathrm{Al}$ & $\mathrm{Si}$ & $\mathrm{P}$ & $\mathrm{S}$ & $\mathrm{Cl}$ & $\mathrm{K}$ & $\mathrm{Ca}$ & $\mathrm{Ti}$ \\
\hline$\% \mathrm{wt}$ & 0.17 & 9.90 & 6.85 & 16.49 & 0.00 & 0.08 & 0.02 & 0.11 & 6.58 & 0.61 \\
\hline Element & $\mathrm{V}$ & $\mathrm{Cr}$ & $\mathrm{Mn}$ & $\mathrm{Fe}$ & $\mathrm{Co}$ & $\mathrm{Ni}$ & $\mathrm{Cu}$ & $\mathrm{Zn}$ & $\mathrm{Sr}$ & $\mathrm{Zr}$ \\
\hline$\% \mathrm{wt}$ & 0.21 & 26.24 & 0.30 & 31.85 & 0.04 & 0.25 & 0.06 & 0.11 & 0.03 & 0.00 \\
\hline
\end{tabular}

0 
Table 2: PGE elemental composition of the slurry fed to the flotation circuit.

\begin{tabular}{|c|c|c|c|c|c|}
\hline Element & $\mathrm{Au}$ & $\mathrm{Pd}$ & $\mathrm{Pt}$ & $\mathrm{Rh}$ & 4E Grade \\
\hline $\mathrm{ppm}$ & 0.0 & 0.5 & 2.2 & 0.3 & 3.0 \\
\hline
\end{tabular}

\section{Mineral Phases of the MG1-MG3 seams}

The mineralogical phases were obtained using XRD and the results are shown on Figure 2. The results show that most of the seams contain more than $70 \%$ chromite. No base metal sulphides that were found confirming that most of the seams are oxidised at this level $(<30 \mathrm{~m})$. The major silicate gangue minerals present are orthopyroxene and plagioclase $(10-20 \%)$, while minor amounts of talc and chlorite are also present.

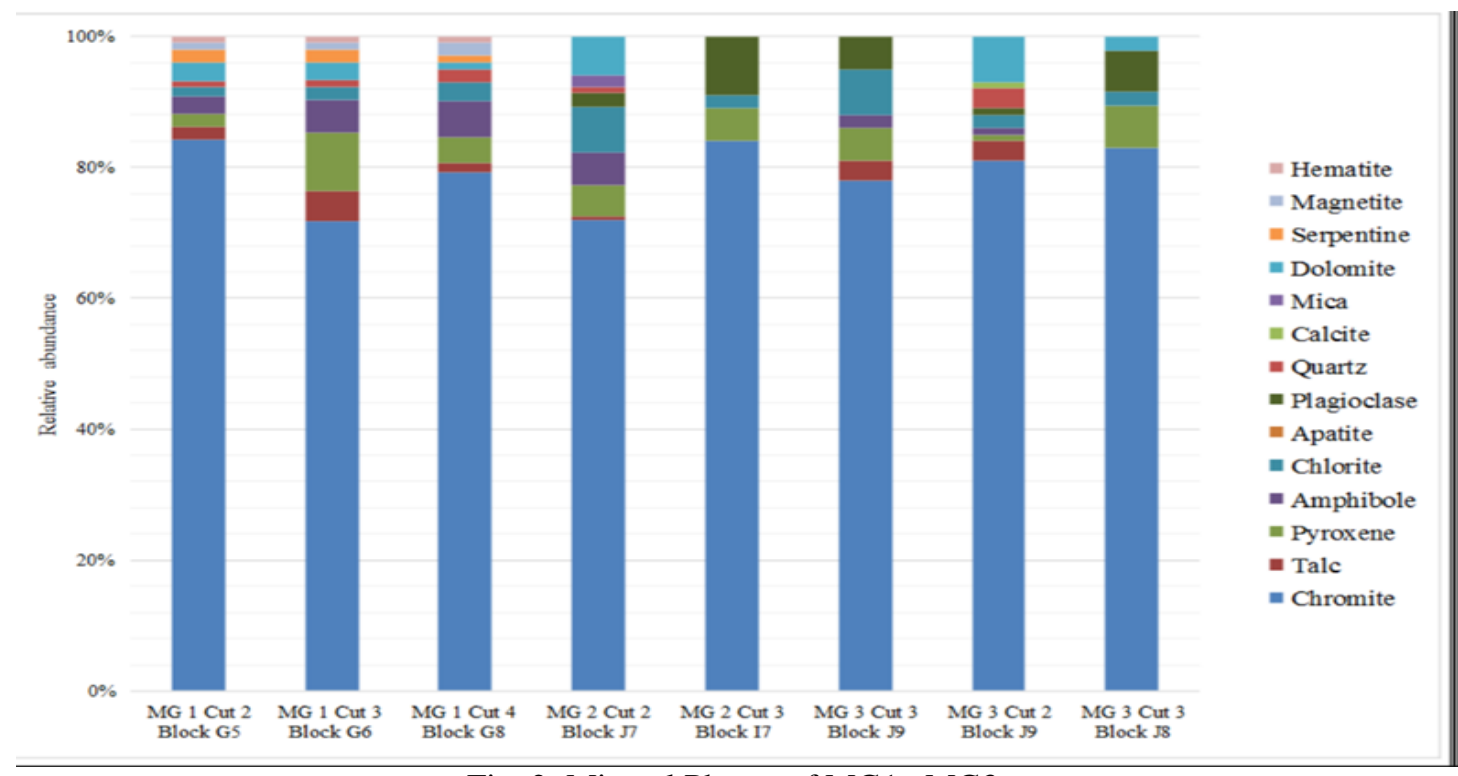

Fig. 2: Mineral Phases of MG1 -MG3.

\section{Surface morphology of the MG4 sample}

SEM was used to determine the surface topography of minerals present in the MG4 ore body and the results are shown in Figure 3. The results confirm the results found using XRD. Major gangue minerals are silicate oxide minerals and Talc.

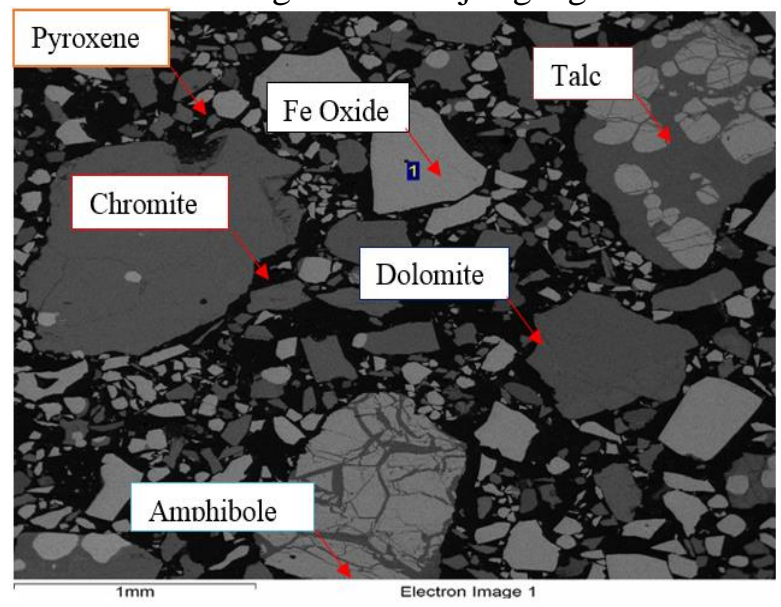

Fig. 3: Micrograph of the MG4 seam. 


\subsection{Flotation Experiments}

The recoveries and the grade of the feed and the rougher concentrate was analysed and the results are shown in Figure 4. Figure 4 illustrate that the feed was upgraded from 3.5-4.8ppm in the rougher section at a recovery of $35 \%$. The figure illustrate that an upgrade factor of three, and unit recovery of $65 \%$, could be a reasonable operating point for a rougher flotation cell provided that the feed conditions are suitable.

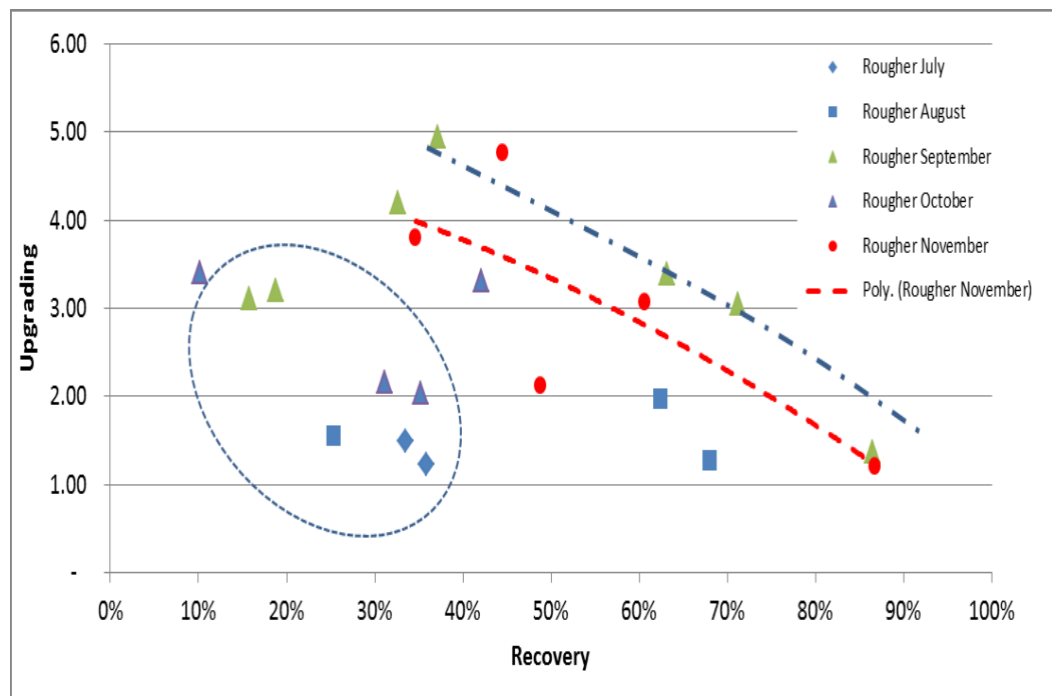

Fig. 4: 4E PGE recovery vs Feed upgrade.

Samples were collected from the flotation section and analysed for selectivity. The Gaudin's efficiency index [9] was used as a feed-grade independent parameter and the results are shown in Figure 4 for the period of August 2017 to February 2018. Long term trend shows an increase in Rougher separation efficiency but this is due to other changes that were conducted during the flotation process such as mill screen parameters and new reagents dosages. The expectation is that the average selectivity should be trending upwards as mining progresses to deeper depth, but there is insufficient data at this point in time to determine whether there is a good correlation. This is subject to ongoing work.

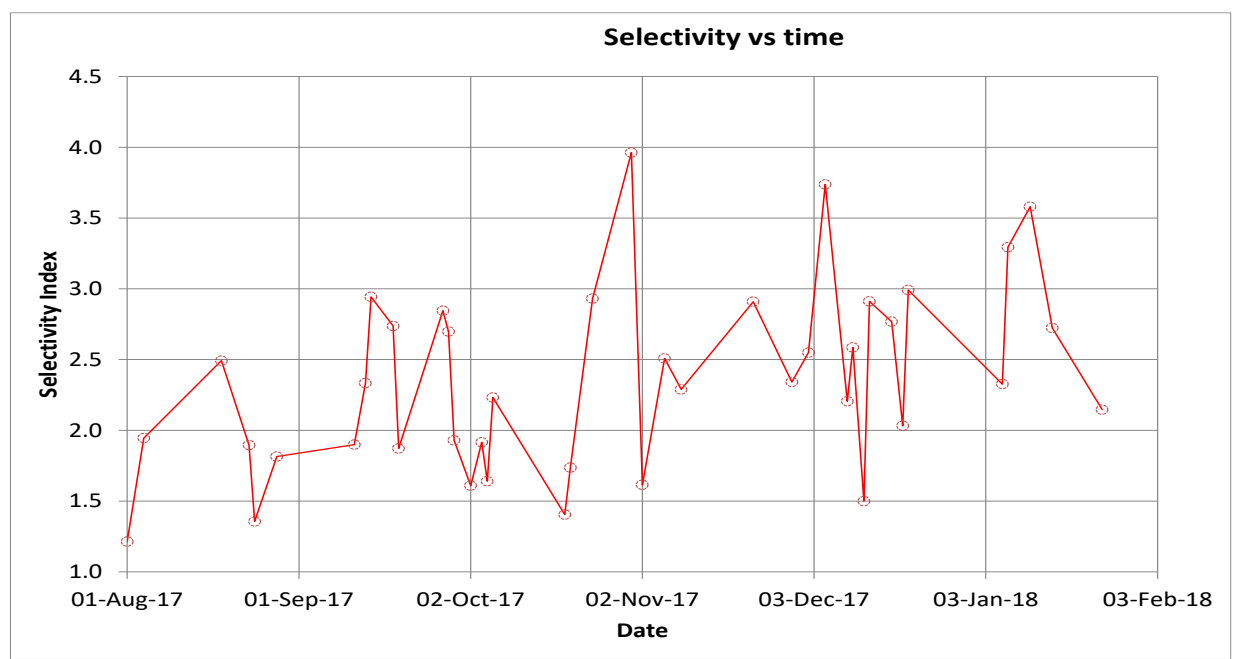

Fig. 4: Selective index of the flotation process.

First indication is that the early January data from greater depth shows better selectivity than the data from mid-January at medium depths as shown in Figure 5. 


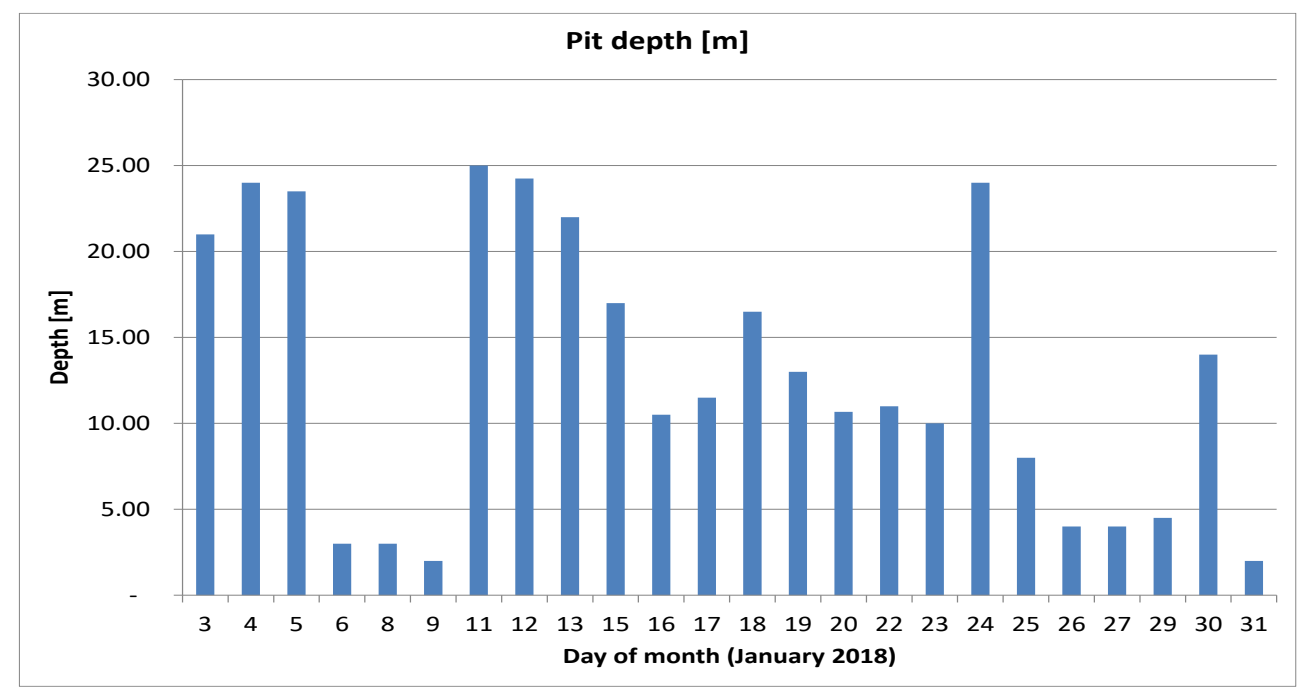

Fig. 6: Mine Pit depth.

\section{Conclusion}

The main principal goal of this study was to investigate the mineralogical characteristics and flotation performances of the weathered ore. This was done for the purpose of examining the behaviour of the ore during the flotation test run and any relationship between the mineralogical characteristics and flotation performance in relation to the grade and recovery of PGEs concentrates. A trend on the degree of weathering and the pit depth was observed although enough data is required to establish relationship. The concentrates from this process still contains a high content of Chromite and there is need to investigate and establish ways of reducing it. MG4 contains the highest amount of PGMs and more data will be generated on this specific seam and come up with a model that will link recoveries to pit depth.

\section{Acknowledgements}

I would like to acknowledge Cronimet Thaba mine for providing the samples, the pilot plant and funding of the Project. I would also want to acknowledge University of Johannesburg for funding the project.

\section{References}

[1] T. E. McCandless, and J. Ruiz, "Osmium isotopes and crustal sources for platinum-group, Mineralization in the Bushveld Complex, South Africa," Geology, vol. 19, no. 12, pp.1225-1228, 1991.

[2] D. J .Z. Ekmekçi, S. A. Bradshaw Allison, and P. J. Harris, "Effects of frother type and froth height on the flotation behaviour of chromite in UG2 ore," Minerals Engineering, vol. 16, no. 10, pp. 941-949, 2003.

[3] N. F. Dawson, "Experiences in the production of metallurgical and chemical grade UG2 chromite concentrates from PGM tailings streams," Journal of the Southern African Institute of Mining and Metallurgy, vol. 110, no. 11, pp. 683690, 2010.

[4] A. V. Tatarnikov, I. Sokolskaya, Y. M. Shneerson, A. Y. Lapin, and P. M. Goncharov, "Treatment of platinum flotation products," Platinum Metals Review, vol. 48, no. 3, pp. 125-132, 2004.

[5] E. Nel, M. Valenta and N. Naude, "Influence of open circuit. Regrind milling on UG-2 ore composition and mineralogy at Impala's UG-2 concentrator," Minerals engineering, vol. 18, no. 8, pp. 785-790, 2005.

[7] Q. I. Wesseldijk, M. A. Reuter, D. J. Bradshaw and P. J. Harris, "The flotation behaviour of chromite with Respect to the beneficiation of UG2 ore," Minerals Engineering, vol. 12, no. 10, pp. 1177-1184, 1999.

[8] S, Ritchie and J. J. Eksteen, "Investigating the effect of slag bath conditions on the existence of multiphase emulsion zones in PGM smelting furnaces using computation fluid dynamics," Minerals Engineering, vol. 24, no. 7, pp. 661675, 2011.

[9] A. Azizi, "A study on the modified flotation parameters and selectivity index in copper flotation," Particulate Science and Technology, vol. 35, no. 1, pp.38-44, 2017. 